pregnant or are in early pregnancy may benefit substantially from screening (with consent). Pregnancy has been a definite cofactor in expression of maternal disease and there is a high rate of HTLV-III infection and disease in infants of seropositive mothers; here again the "gift" relation applies.

\section{Conclusion}

Aside from the selected settings mentioned, the arguments for "routine" screening are not as logical as they at first appear; at best they confer very limited benefits that can be as easily, if not better achieved, by other approaches. The risks to the individual patient of indiscriminate screening are considerable. If a potent vaccine or an effective anti-HTLV-III treatment were to become available the balance would abruptly change to the benefit of the individual. The HTLV-III antibody test is not "just another test"-testing should be anything but routine in view of the potential consequences for those found positive. Too many patients have already suffered from a failure to appreciate this single fact. If we are to have any meaningful impact on the spread of this infection and its tragic consequences counselling on safe sex and positive behavioural change must be taken into the public arena without further delay. In the present circumstances before testing doctors must ask themselves: Why are we testing and what benefits, to the individual or to society, derive uniquely from testing? How can we achieve the benefits of testing by other means? Is the potential harm resulting for the patient justified by the benefits? Do we have the means to deal with it?
We express particular thanks to our patients and to all colleagues whose discussions contributed to the formulation of this paper.

\section{References}

1 Curran JW, Morgan M, Hardy AM, Jaffe HW, Darrow WW, Dowdle WR. The epidemiology of AIDS: current status and future prospects. Science 1985;229:1352-7.

2 Weber J, Pinching AJ. The clinical management of AIDS and HTLV-III infection. In: Miller D, Weber J, Green J, eds. The management of AIDS patients. Basingstoke: Macmillan Press, Weber J, Gree $1986: 1-33$.

3 Pinching AJ, Jeffries DJ. AIDS and HTLV-III infection: consequences for obstetrics and perinatal medicine. Fournal of Obstetrics and Gynaecology 1985;92:1211-7.

4 Miller D, Green J. Psychological support and counselling for patients with acquired immune deficiency syndrome (AIDS). Genitourinary Medicine 1985;61:273-8

5 Green J. Reduction of risk in high-risk groups. In: Miller D, Weber J, Green J, eds. The management of AIDS patients. Basingstoke: Macmillan Press, 1986:175-85.

6 Miller D, Green J, Farmer R, Carroll G. A "pseudo-AIDS" syndrome following from a fear of AIDS. Br f Psychiatry 1985;146:550-1.

7 Department of Health and Social Security. AIDS booklet 2. Information for doctors concerning the introduction of the HTLV-III antibody test. Heywood, Lancs: DHSS Health Publications Unit, 1985 .

8 Center for Disease Control. Recommendations for preventing transmission of infection with human $T$ lymphotropic virus type III/lymphadenopathy-associated virus in the workplace. MMWR 1985;34:681-95.

9 Levi A, Houghton D, Jenner E. Nursing: infection control aspects of care. In: Miller D, Weber J, Green J, eds. The management of AIDS patients. Basingstoke: Macmillan Press, 1986:93-108.

10 Dinsdale RCW. Viral hepatitis, AIDS and dental treatment. London: British Dental foumal, 1985.

11 Confederation of Health Service Employees (COHSE). Guidelines for health staffs dealing with patients suffering from acquired immune deficiency syndrome (AIDS) or with AIDS virus. Banstead: COHSE, 1985.

12 Miller D, Green J, McCreaner A. Organising a counselling service for AIDS-related problems. Genitourin Med 1986;62:114-9.

Accepted 3 February 1986

\title{
"Don't tell me on a Friday"
}

\author{
THOMAS RICHARDS
}

I am a gay man who discovered last summer that I had antibodies to human T cell lymphotropic virus III (HTLV-III). For me there are two central strands to the question of whether or not people should be tested for such antibodies: firstly, will knowing that you are positive help your own health; and, secondly, will it make you more or less likely to infect others?

Like many people, when I first discovered that I was antibody positive I felt shock and disorientation. I woke up in the mornings shaking, had problems sleeping, and lost my appetite. I wrote a will, drank heavily, and seriously considered suicide. I thought, like others, that I was bound to develop acquired immune deficiency syndrome (AIDS). (Capital Gay recently reported that a Newcastle conference on AIDS had been told of six people who had killed themselves on discovering that they were positive.)

But, through good counselling from both the doctor at the special clinic and a clinical psychologist, after three to four weeks I got used to being positive. I was put in touch with a gay self help group in London (which now has imitators in other parts of the country) called Body Positive. The support, both practical and emotional, that both the psychologist and Body Positive gave were all important for me. Where I should have been without their help I dare not consider.

Such help should, I believe, be available to everybody immediately that they find out that they have antibodies. This belief explains my title because people should not be given this news if an appointment with a psychologist cannot be arranged until after a weekend-the first 72 hours are the worst. Given the restricted counselling facilities that are as yet available, I think it inevitable that doctors are going to have to make full use of voluntary organisations such as Body Positive.
Knowing that you are positive gives you a chance to alter your lifestyle. It becomes more likely that you will adopt a healthier diet and cut down on alcohol, tobacco, or cannabis. As an actor I decided that stress was my main problem, and I took up yoga for the first time in my life with great success.

The most important question is-will knowing that you are positive alter your sexual behaviour? Gays in this country have up until now followed a free and easy existence. All we risked living in the "fast lane" was, it seemed, the occasional social disease. Clearly we must adopt a more responsible attitude, and it does seem that gay men who are discovered to be positive and who are properly counselled do behave responsibly and change their sexual practices. They follow the "safe sex" guidelines suggested by organisations such as the Terrence Higgins Trust.

While in a perfect world all gay men should for the last two years have adopted safer sexual practices, including the use of condoms, this is not a perfect world and they have not. The reality is that at one o'clock in the morning after four or five pints in a gay pub or club gay men go home with each other without checking that one of them has condoms.

I do not advocate the compulsory testing of gay men. But so long as we understand the test and its limitations and so long as good counselling is available I think we should be encouraged to take the test-both for our own good and that of the community, gay and straight. The decision must, however, remain a personal one. My experience-and that of St Mary's Hospital-is that those who change their behaviour most are those who are tested, found positive, and properly counselled.

Thomas Richards is a pseudonym. 